Dragan D. Milković

Assistant Professor University of Belgrade

Faculty of Mechanical Engineering

Goran Ž. Simić

Full Professor

University of Belgrade

Faculty of Mechanical Engineering

Jovan D. Tanasković

Assistant Professor University of Belgrade

Faculty of Mechanical Engineering

Vojkan J. Lučanin

Full Professor

University of Belgrade

Faculty of Mechanical Engineering

Saša Z. Radulović

Researcher

University of Belgrade

Faculty of Mechanical Engineering

\section{Uncertainty of the Wheel-rail Angle of Attack Measurements Using Laser Based Wayside System}

The angle of attack is an important wheel-rail contact parameter. Together with wheel-rail contact forces it serves for estimation of the rail vehicle curving performances. This paper analyses measurement uncertainty of the specially designed laser system for measurements of the wheel-rail angle of attack, with emphasis on the importance of the theoretical aproach for selection of the appropriate measuring principle and for identifing all influential factors. The influence of the correct installation of the system on results is also considered. In order to evaluate quality of the analysis, some measurement results are presented and compared with the results of multibody system (MBS) simulation using specialized computer package VAMPIRE Pro.

Keywords: rail vehicles; angle of attack, laser based measurements, wayside system, Multibody system simulations.

\section{INTRODUCTION}

The angle of attack (AOA) $\alpha$ refers to the yaw angle of the wheelset relative to the track (Figure 1) resulting from the wheelset inability almost never to perfectly align with the track tangent during curve negotiation. The phenomenon is the most pronounced in case of the leading wheelset and in the sharp curves. Considering its importance for estimation of the railway vehicles curving performances, this paper presents the development of laser based system for AOA measurements installed on the track, with emphasis on the factors influencing uncertainty of the whole measurement process depending on the selected measuring principle and laser device quality.

Other similar systems using possible measuring principles [1-4] presented by other authors were also analysed. Common to all systems, whether installed on the tracks or on the vehicles, is that they use different sensors and transducers for detecting the wheel position relative to rail. Angle between the reference wheel line and the reference rail line in the horizontal plane determines wheel to rail angle of attack. Any horizontal line on outer or inner part of the wheel vertical plane surface can be used as the reference wheel line. Any longitudinal generatrix of the rail can be adopted as the reference rail line.

Due to the guiding principle of the rail vehicles, AOA has the highest values in curves. As a result increased lateral guiding forces and wear of the wheel and rail appear. Consequently, derailment of the railway vehicle may occur. Therefore the AOA measurements in sharp curves are in the focus of the performed research.

Received: October 2015, Accepted: November 2015

Correspondence to: Asst. Prof. Dragan Milković

Faculty of Mechanical Engineering,

Kraljice Marije 16, 11120 Belgrade 35, Serbia

E-mail: dmilkovic@mas.bg.ac.rs

doi:10.5937/fmet1701069M

(C) Faculty of Mechanical Engineering, Belgrade. All rights reserved
The measurements can be done in two general ways: with a measurement system installed on a vehicle (vehicle based), or placed on the track (wayside or track based). Vehicle based systems are more complex because the different time dependent relative movements between vehicle parts and rail should be measured and then processed. Their advantage is that AOA of one wheel can be recorded along the track, i.e. on different track configurations (primarily different curve radii). On the other hand, wayside systems, usually installed in sharp curves, provide data about AOA of all wheels of one train, passing over the equipped track section.

This paper presents wayside system for AOA measurements using one laser device.

\section{WAYSIDE SYSTEM FOR MEASUREMENTS OF ANGLE OF ATTACK USING LASER DEVICE}

One of the possible measuring principles uses two parallel laser beams placed perpendicularly to the tangent of the rail. In this case, within preparation, it is necessary to precisely measure the distance between each laser and the rail reference line as well as to achieve high perpendicularity of each laser to the rail. During the measurements it is necessary to trigger both lasers simultaneously and depending on the train speed in time, in order not to miss the wheel passing over the measuring system. Figure 1 presents the measurement principle using two laser devices.

From the measured distance between the lasers and the wheel $L_{1 \mathrm{w}}, L_{2 \mathrm{w}}$, previously known distances between both lasers and the rail reference line $L_{1 \mathrm{r}}$ and $L_{2 \mathrm{r}}$ and known distance $D$ between the lasers, the angle of attack can be calculated as:

$$
\alpha=\operatorname{arctg}\left[\frac{\left(L_{1 w}-L_{1 r}\right)-\left(L_{2 w}-L_{2 r}\right)}{D}\right]
$$

or considering the maximum expected angle of attack $\alpha$ for vehicles intended for use on standard track gauge, 
which is about $2^{\circ}(35 \mathrm{mrad})$ :

$$
\alpha \approx \frac{\left(L_{1 w}-L_{1 r}\right)-\left(L_{2 w}-L_{2 r}\right)}{D}
$$

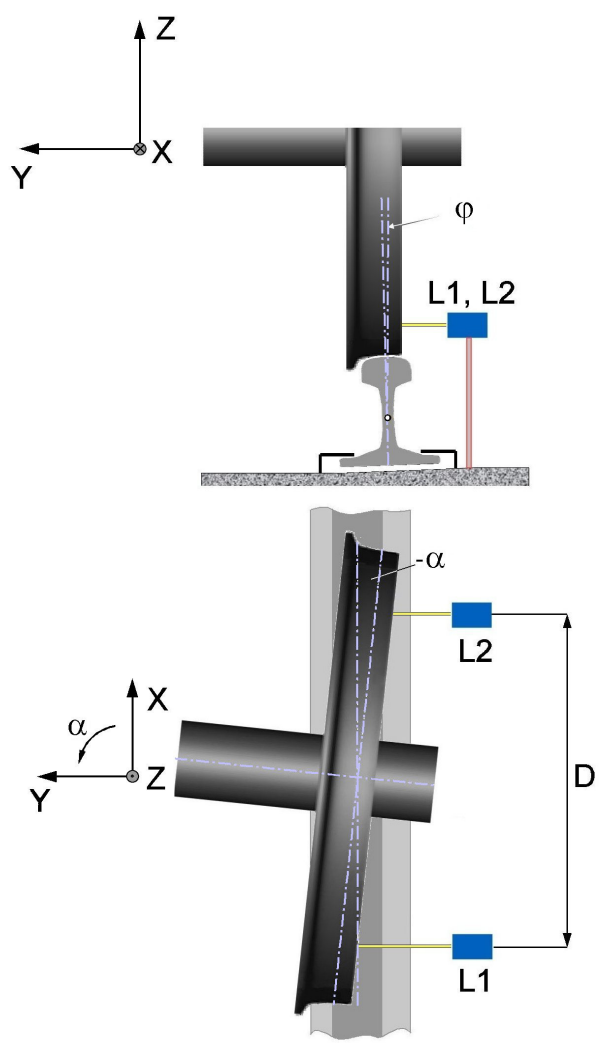

Figure 1. Measuring using two laser beams

Laser based measurements depend on the laser beam resolution, influencing measuring accuracy. Also, they depend on laser power, influencing maximum possible distance between the laser and the measuring object.

A simpler and equally reliable measurement of AOA can be achieved with one laser device with an appropriate measurement procedure (Figure 2) [5, 6].

In principle, measuring is possible under assumptions that rail axis corresponds to the direction of the wheel forward movement, and that AOA is the angle between the wheel back surface and the direction of forward movement. Taking into account that one of the most important function of the rail is to guide a wheel, this assumption can be accepted as sufficiently accurate. We assume that the stationary conditions and balance of the forces are achieved, so except at the entrance and at the end of the curve, the AOA will approximately be constant during measurement [3].

From the typical cross-section of a rail vehicle wheel shown in Figure 2, it can be seen that the back side of the wheel has a plane annulus surface, suitable for measurement. The radius of the outer circular boundary of the annulus $r_{1}$ is $10 \mathrm{~mm}$ bigger than nominal rolling radius $r_{\mathrm{o}}$ of the new wheel. As a result of the wheel wear, over time, this difference becomes greater than $10 \mathrm{~mm}$. With the new wheels, the radius of the inner circular boundary of the plain ring $r_{2}$ is typically $70 \mathrm{~mm}$ lower than $r_{\mathrm{o}}$, and with the wheels at the wear limit, the radius is typically $30 \mathrm{~mm}$ lower than $r_{\mathrm{o}}$.

The height of the horizontal laser beam was chosen approximately $5 \mathrm{~mm}$ below the top of the rail (TOR), thus providing, without changing the laser vertical position, the recording of the rail side referent line, as well as the recording of the wheel distance at some effective measuring length $s$. In this case, for the commonly used wheels with average radius of about $400 \mathrm{~mm}$, an available effective measuring length is about $125 \mathrm{~mm}$.

In case the laser beam height was set to $30 \mathrm{~mm}$ above TOR, the effective measuring length can be increased up to $350 \mathrm{~mm}$. The laser position higher than $30 \mathrm{~mm}$ above TOR will in case of a worn wheel produce two linear segments and can cause problems associated with the interference with the vehicle contour.

However, if the laser beam is being set above TOR, recording of the rail reference line requires an additional metal plate leaning against the inner plane surface of the rail head. This additional step may further affect measurement accuracy.

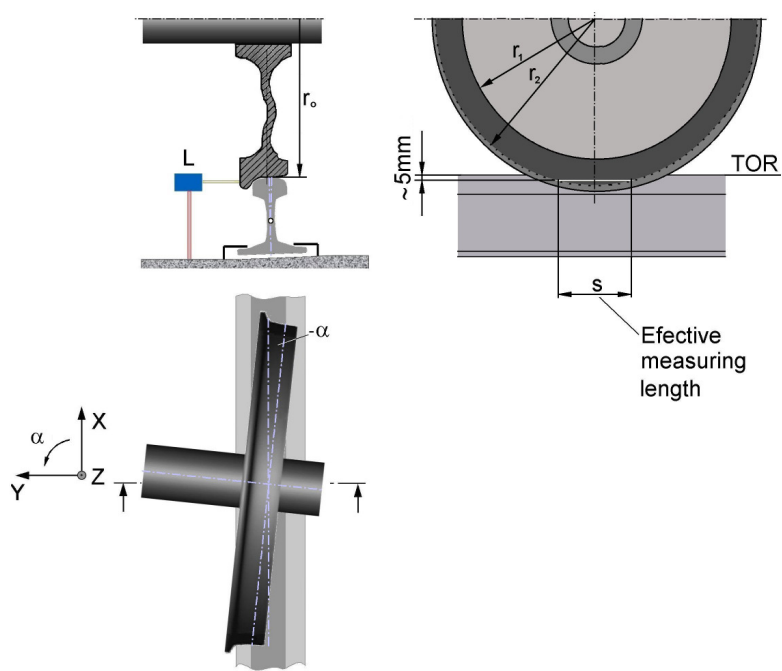

Figure 2. Measuring principle using one laser beam

\subsection{The influence of the track curvature}

The angle obtained by using measuring principle with one laser beam should eventually be corrected considering the influence of the track i.e. the rail curvature in the horizontal plane on measuring uncertainty.

For determination of the rail reference line, the following should be considered. The design of the developed system allows maximum movement of the laser along the rail reference line $275 \mathrm{~mm}$. The minimum curve radius on the main track lines is limited to $150 \mathrm{~m}$ and can be found only at switches. In that, the most unfavourable case, length of sagitta of corresponding rail arc is $0.063 \mathrm{~mm}$. Considering that this is the greatest possible value, the reference line of the rail can be approximated as a straight line parallel to $\mathrm{x}$ axis (Figure 2).

Assume that the wheel is placed radially while passing through the curve, i.e. that the wheel to rail AOA is equal to zero (Figure 3 ).

Three different positions of the wheelset during passing through the laser $\mathrm{L}$ measuring range are numbered 1 to 3 . They represent: the entering of the wheelset the laser beam line, central position of the 
wheel relative to the laser and moment of the wheel leaving the laser measurement line. Measured distances from the laser to the wheel in corresponding time $t_{1}$ to $t_{3}$ are marked as $L_{1}$ to $L_{3}$.

The difference between measured distances from the laser to the wheel back surface $\left(L_{1}-L_{2}\right)$, resulting from the rail curvature, produces the following deviation from the straight line when $L(t)$ transformed to $L(s)$ based on known speed $V$ :

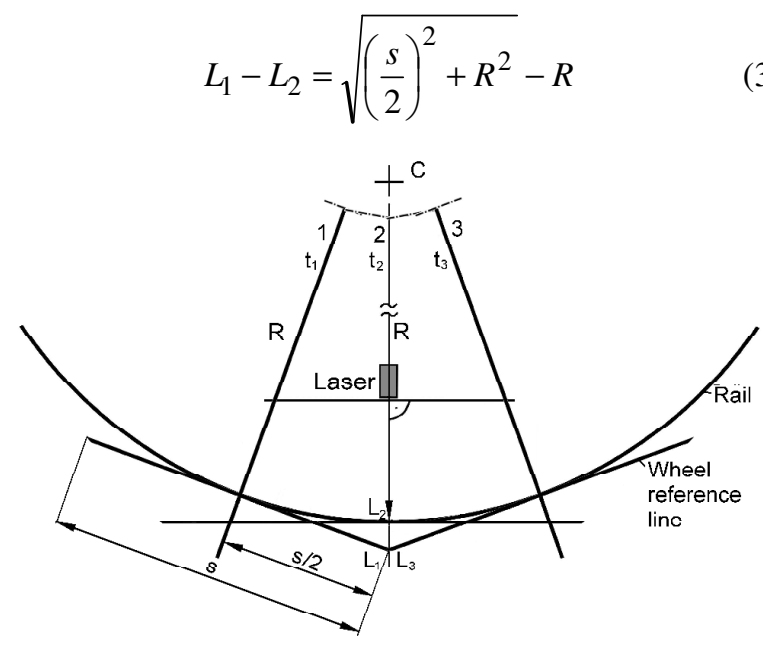

Figure 3. Radial steering of the wheelset during curve negotiation

In the case of maximum expected effective measuring length $s=350 \mathrm{~mm}$ and the minimum rail radius $150 \mathrm{~m}$, the difference resulting from the rail curvature is only $0.1 \mathrm{~mm}$, hence can be neglected.

Theoretically, the measurement deviation caused by the rail curvature can be neglected due to the following two reasons: (a) it has low value and (b) for further analysis it is compensated using least square method (see below).

\subsection{The influence of the laser positioning}

Figure 4 presents the developed system for determining relative position between the wheel and the rail and AOA measurements.

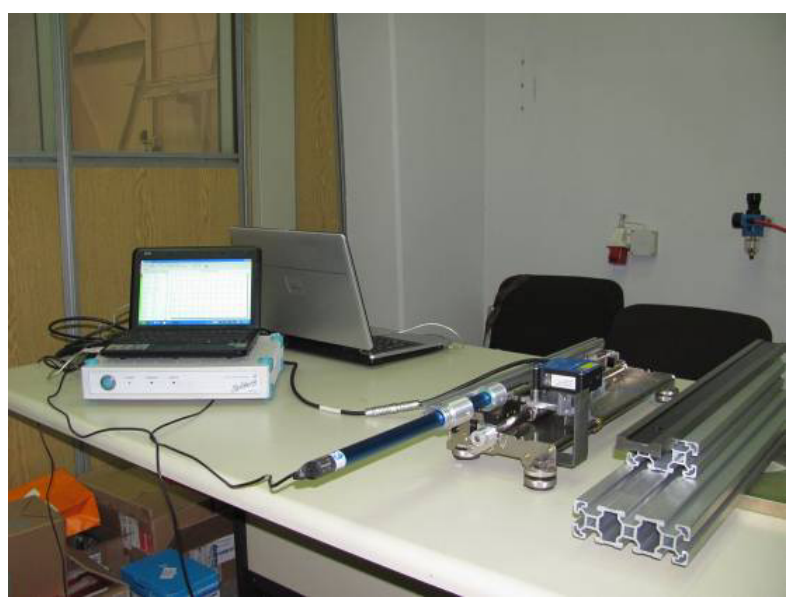

Figure 4. System for wheel to rail AOA measurements

As the optical device of the system we used the laser beam Micro Epsilon OPTO NCDT 1700-100 [7], marked as 1 in Figure 5.

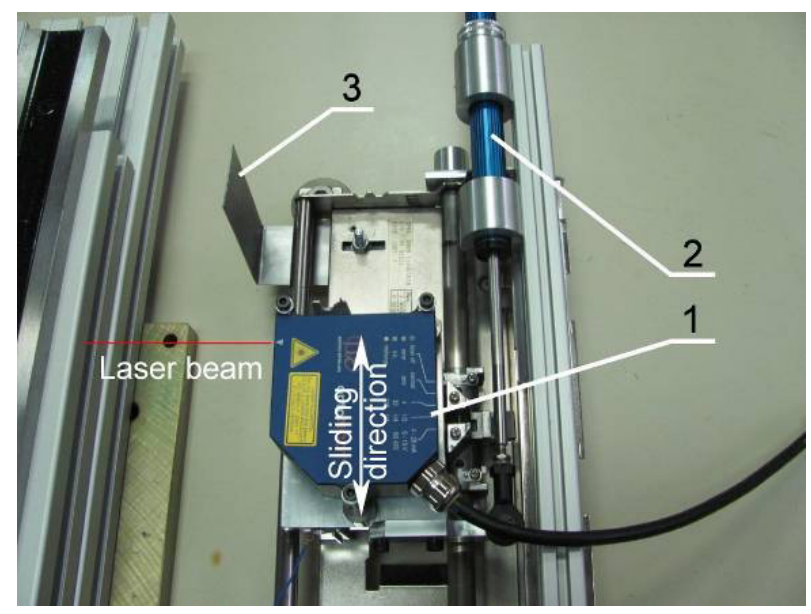

Figure 5. Details of the system for wheel to rail AOA measurements

The measuring range $L$ of the laser is from 70 to $170 \mathrm{~mm}$. In order to provide the correct positioning on the track, the laser beam is placed on longitudinally sliding stand. The laser beam position along the slider was measured using the linear potentiometer transducer Penny Giles SLS190/275 mm (Figure 5, item 2). Since the distances measured with the laser device and with potentiometer transducer were recorded by using two acquisition systems, the measurements were synchronized by using a blind cover, fixed on the slider stand (Figure 5, item 3). This cover defines the position of entering of the laser device the measuring range and zero position of the displacement transducer.

The accuracy of the developed system can be influenced by the correct laser device positioning, i.e. the laser beam should be perpendicular to the rail tangent. The verification of the deviation angle from the ideal perpendicular position $\gamma$ is performed by using the system itself, as shown in Figure 6, by recording the laser to rail distance while sliding the laser from one guide end to another.

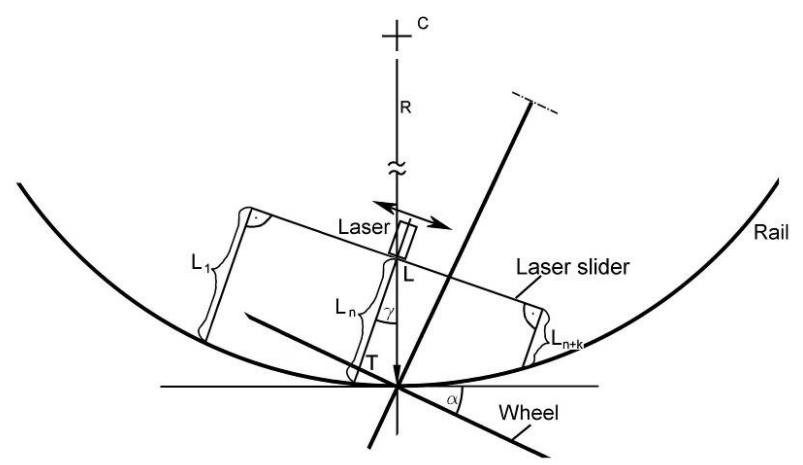

Figure 6. Check of the laser beam perpendicularity to the rail tangent (exaggerated non-perpendicular illustration)

As concluded above, the arc of the recorded rail curvature at such a small length could be approximated as a straight line. So, it is enough to read the difference between end distances $L_{1}-L_{\mathrm{n}+\mathrm{k}}$ to have an indication how much to move one end of the system base in order to correct the laser position relative to rail. Note at this point that the displacement of $1 \mathrm{~mm}$ perpendicular to the guide axis causes change of the angle between the laser beam and the tangent to the track/rail axis equal to: 


$$
\begin{aligned}
\gamma & =\operatorname{arctg}\left(\frac{\text { deviati on of the base support position }}{\text { guide length }}\right)= \\
& =\operatorname{arctg}\left(\frac{1}{275}\right) \approx\left(\frac{1}{275}\right)=3.6 \mathrm{mrad}=0.21^{\circ}
\end{aligned}
$$

Non-perpendicularity between the laser beam and the slider axis may also influence the measurement of the rail reference line. Comparing to other ones, this influence is insignificant and was neglected, especially when considering that it was adjusted and checked in the laboratory, during the laser system mounting.

The analysis of $\gamma$ influence on measuring uncertainty and determination of their allowable limit values is presented below. Figure 7 presents the measurements in case the laser beam $\mathrm{L}$ is ideally perpendicularly positioned and $\mathrm{L}^{\prime}$ in the case of the non-perpendicular laser beam for an angle $\gamma$. Figure 7 presents two wheel positions during passing by the laser in time $t$ and $t+\Delta t$.

Measurement principle using one laser beam is based on the expression:

$$
\alpha=\arctan \left(\frac{\Delta L}{V \cdot \Delta t}\right) \approx \frac{\Delta L}{V \cdot \Delta t}=\frac{\Delta L}{s}
$$

where:

$\Delta L$ - the distance change between the wheel back surface and the laser during measuring interval $\Delta t$,

$s=V \cdot \Delta t-$ the move of the wheel along the rail during interval $\Delta t$.

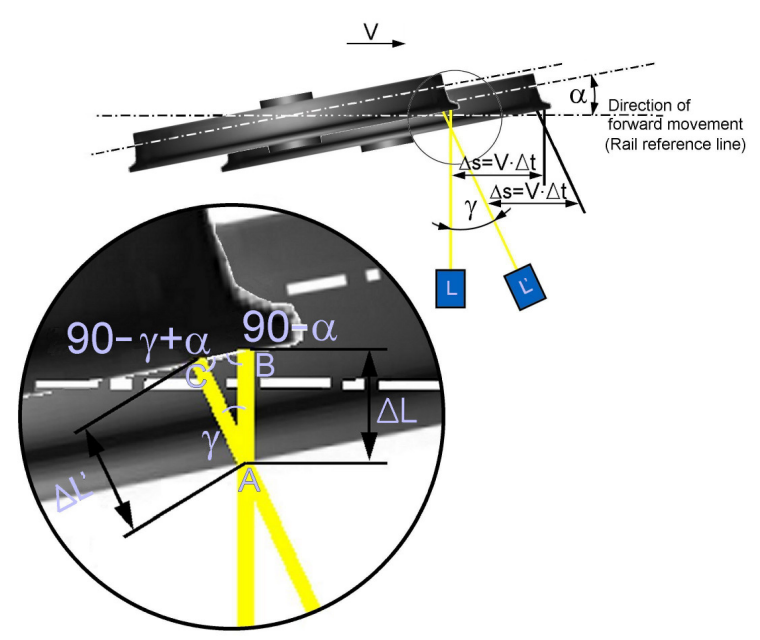

Figure 7. Geometric representation of the influence of $\alpha$ and $\gamma$ on measurement accuracy

The dependence of $\Delta L$ on the laser beam direction and its perpendicularity to the rail can be determined by using the representation given in Figure 7. L presents the direction of the laser beam in case of the ideal position, perpendicular to the rail. L' represents a case when the deviation angle $\gamma$ exists. Notice the triangle $A B C$. For the clarity of the analysis, two laser positions are selected so that both of them in the moment $t+\Delta t$ are directed to point $A$ of the wheel surface. As a result of assumed geometry, points $\mathrm{B}$ and $\mathrm{C}$ represent the laser beams reflection points in the moment $t$. The angle by vertex $\mathrm{A}$ is $\gamma$, by vertex $\mathrm{B}$ is $90^{\circ}-\alpha$, and by vertex $C$ the angle is $90^{\circ}-\gamma+\alpha$. Applying the Law of Sines to triangle $\mathrm{ABC}$ results in the following relation:

$$
\Delta L^{\prime}=\Delta L \cdot \frac{\sin \left(90^{\circ}-\alpha\right)}{\sin \left(90^{\circ}-\gamma+\alpha\right)}
$$

Another influencing factor on $\Delta L$ measurement is the laser measurement uncertainty. The manufacturer declared the uncertainty of $0.12 \%$ of the measuring range for deviation angle $\gamma$ up to $5^{\circ}$ about each axis caused by light diffusion [7]. For nominal measuring range (the distance between laser and measuring point) of $120 \mathrm{~mm}$ it results in uncertainty of $\mathrm{u}(L)=0.14 \mathrm{~mm}$.

The influence of the laser resolution can be neglected since it is only $6 \mu \mathrm{m}$. Assuming a uniform distribution of the deviation angle we are on the safe side when including uncertainties caused by both influences:

$$
\begin{aligned}
\mathrm{u}(\Delta L) & =\sqrt{\left(\frac{\left|\Delta L-\Delta L^{\prime}\right|}{\sqrt{3}}\right)^{2}+\left(\frac{\mathrm{u}(L)}{\sqrt{3}}\right)^{2}}= \\
& =\sqrt{\left(\frac{\Delta L}{\sqrt{3}} \cdot\left|1-\frac{\sin \left(90^{\circ}-\alpha\right)}{\sin \left(90^{\circ}-\gamma+\alpha\right)}\right|\right)^{2}+\left(\frac{\mathrm{u}(L)}{\sqrt{3}}\right)^{2}}
\end{aligned}
$$

Based on (5) the combined measurement uncertainty [8] of $\alpha$ is estimated as:

$$
\begin{aligned}
\mathrm{u}(\alpha) & =\sqrt{\left[\frac{\partial(\alpha)}{\partial(\Delta L)} \mathrm{u}(\Delta L)\right]^{2}+\left[\frac{\partial(\alpha)}{\partial(s)} \mathrm{u}(s)\right]^{2}}= \\
& =\sqrt{\left[\frac{\mathrm{u}(\Delta L)}{s}\right]^{2}+\left[-\frac{\Delta L}{s^{2}} \mathrm{u}(s)\right]^{2}}
\end{aligned}
$$

Using (5) it follows:

$$
\mathrm{u}(\alpha)=\alpha \cdot \sqrt{\left[\frac{\mathrm{u}(\Delta L)}{\Delta L}\right]^{2}+\left[\frac{\mathrm{u}(s)}{s}\right]^{2}}
$$

\subsection{Travelled distance speed measurement uncertainty}

The same laser system was used for wheel travelled distance measurements and for train speed measurements. Depending on the speed $V$ the minimum sampled travel distance ("unit") is:

$$
s_{u}=\frac{V}{f_{s}}
$$

This value represents one "division" on a virtual travel distance meter. The sampling rate of the laser is $f_{s}=2500 \mathrm{~Hz}$. In the sharp curves with radius up to $400 \mathrm{~m}$, the maximum speed is limited by the maximum allowable cant deficiency [9], i.e. resulting in unbalanced lateral acceleration. The resulting maximum speed in this case is approximately $28 \mathrm{~m} / \mathrm{s}(100 \mathrm{~km} / \mathrm{h})$. From the (10) the "unit" sampled travel distance in that case is $s_{u}=0.0112 \mathrm{~m}=11.2 \mathrm{~mm}$. For lower speeds this value is accordingly lower.

Practically the "unit" $s_{u}$ is "calibrated" using the known distance between two adjacent wheelsets (wheelbase) passing by the laser. The highest 
measurement uncertainty is in the case of the smallest wheelbase. At the European Railways this is the case with freight car standard bogies with the wheelbase $p=1.8 \mathrm{~m}$ and tolerance $\Delta p= \pm 0.002 \mathrm{~m} \mathrm{[10]}$. Combined uncertainty of the wheelbase measurement assuming uniform distribution [8] is:

$$
\mathrm{u}(p)=\sqrt{\left(\frac{s_{u}}{2 \sqrt{3}}\right)^{2}+\left(\frac{\Delta p}{\sqrt{3}}\right)^{2}}
$$

The results show that the influence of deviation from perpendicularness of the laser beam to the rail direction up to $\pm 5^{\circ}$ has a negligible influence on measured AOA. It means that the direction of the wheel movement presents the rail reference line and if $\gamma$ kept within $\pm 5^{\circ}$ it is not necessary to record the rail reference line. Relative measurement error is almost independent of AOA $\alpha$, but it depends on the running speed $V$ of the passing vehicle. It is relatively easy to keep $\gamma$ within limits $\pm 5^{\circ}$ and in that way to achieve low measurement uncertainty.

Any distance $s$ in further analysis of AOA is a multiplier of the "unit" $s_{\mathrm{u}}$ and therefore is:

$$
\frac{\mathrm{u}(s)}{s}=\frac{\mathrm{u}(p)}{p}
$$

Just to notice that deviation of the laser beam from perpendicularity to the rail has the same influence on the "calibration" with $p$ as well as for any displacement along the rail i.e. it is self-compensated.

In the case of the maximum expected speed of $100 \mathrm{~km} / \mathrm{h}$ and the minimum wheelbase distance $p=1.8 \mathrm{~m}$ (the most unfavourable case) it will be:

$$
\frac{\mathrm{u}(p)}{p}=0,18 \%
$$

The speed of the passing vehicle is determined from known wheelset distance $p$ and corresponding time interval between passings of two wheelsets in front of the laser $t_{p}$ :

$$
V=\frac{p}{\Delta t_{p}}
$$

Consequently, the speed measurement uncertainty, having in mind the negligible uncertainty of sampling time, is:

$$
\frac{\mathrm{u}(V)}{V}=\sqrt{\left[\frac{\mathrm{u}(p)}{p}\right]^{2}+\left[\frac{\mathrm{u}(\Delta t)}{\Delta t}\right]^{2}} \approx \frac{\mathrm{u}(p)}{p}
$$

Table 1 shows the calculated uncertainty of AOA for different angles $\alpha$ and $\gamma$ different speeds of passing vehicles and travelled distance $s=100 \mathrm{~mm}$.

\subsection{Other influences on the angle of attack measurements}

Other influences on AOA measurements are: the surface roughness, vibrations as well as the rail deformations caused by wheel passing and other imperfections. The maximum surfaces roughness appears in the case of new hot rolled rails and/or wheels immediately after their machining, with typical values of $25 \mu \mathrm{m}$ for each. This value is negligible for the determination of the rail or wheel reference line. Generally, roughness and other geometrical imperfections cause small vibrations and noise to the recorded signal. Both influences can be compensated using the least square method for processing of the recorded rail and wheel reference lines.

Deformations i.e. displacement of the rail in lateral direction during the wheel passing over the measuring point, caused by wheel-rail contact forces, can be continuously measured as a distance to rail during approaching and after passing of the wheel. Thus, it is possible to compensate its influence on measurement results. Since the measurement position is chosen in the middle between two adjacent slippers, the small change of deflection is quite symmetric and can be compensated by linear regression applied to the measurement results (see Figure 12).

\section{IN SITU MEASUREMENTS}

Figure 8 presents the system for the wheel-rail angle of attack measurements during positioning for in situ measurements and checking of its perpendicularity to the rail.

Considering that during the measurements system is placed inside the tracks and the train passes over it, for precaution the system is covered as presented in

\begin{tabular}{|c|c|c|c|c|c|c|c|c|}
\hline $\begin{array}{c}\mathrm{V} \\
(\mathrm{km} / \mathrm{h})\end{array}$ & $\begin{array}{c}\alpha \\
\left({ }^{\circ}\right)\end{array}$ & $\begin{array}{c}\alpha \\
(\mathrm{mrad})\end{array}$ & $\begin{array}{l}\gamma \\
\left({ }^{\circ}\right)\end{array}$ & $\begin{array}{c}\mathrm{u}(\Delta \mathrm{L}) \\
(\mathrm{mm}) \text { eq. }(7)\end{array}$ & $\begin{array}{c}\mathrm{u}(\Delta \mathrm{L}) / \Delta \mathrm{L} \\
(\%)\end{array}$ & $\begin{array}{c}\mathrm{u}(\mathrm{s}) / \mathrm{s} \\
(\%) \\
\text { eq. }(12)\end{array}$ & $\begin{array}{l}\text { Relative } \\
\text { error } \\
(\%)\end{array}$ & $\begin{array}{l}\mathrm{u}(\alpha) \\
\text { (mrad) } \\
\text { eq. (9) }\end{array}$ \\
\hline \multirow{3}{*}{100} & \multirow{3}{*}{0.5} & \multirow{3}{*}{8.7} & 0.5 & 0.08316 & 0.08314 & 0.10 & 0.18 & 0.20 \\
\hline & & & 1 & 0.08314 & 0.08314 & 0.10 & 0.18 & 0.20 \\
\hline & & & 5 & 0.08506 & 0.08315 & 0.10 & 0.18 & 0.20 \\
\hline 100 & 1 & 17.5 & 5 & 0.08602 & 0.08317 & 0.05 & 0.18 & 0.18 \\
\hline 100 & \multirow{3}{*}{2} & \multirow{3}{*}{34.9} & \multirow{3}{*}{5} & 0.08506 & 0.08315 & 0.02 & 0.18 & 0.18 \\
\hline 70 & & & & 0.08506 & 0.08315 & 0.02 & 0.12 & 0.13 \\
\hline 30 & & & & 0.08506 & 0.08315 & 0.02 & 0.05 & 0.06 \\
\hline
\end{tabular}
Figure 9.

The cover has a small longitudinal groove providing passing of the laser beam during measurements.

Table 1. The angle of attack uncertainty influences 


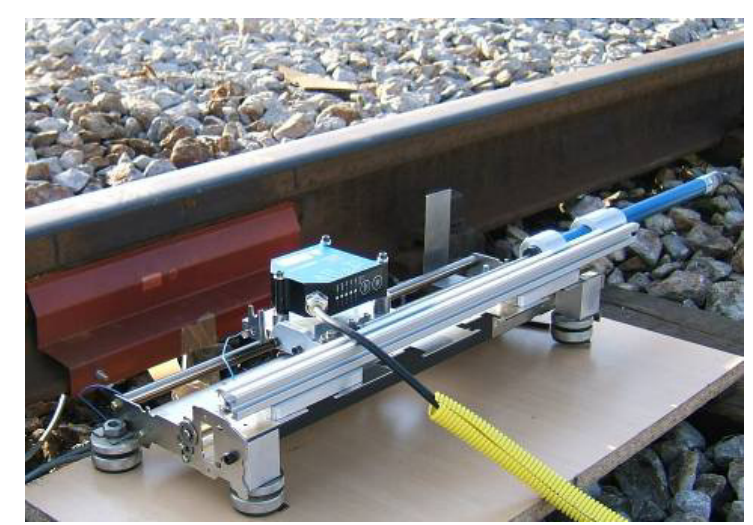

Figure 8. Laser system during positioning

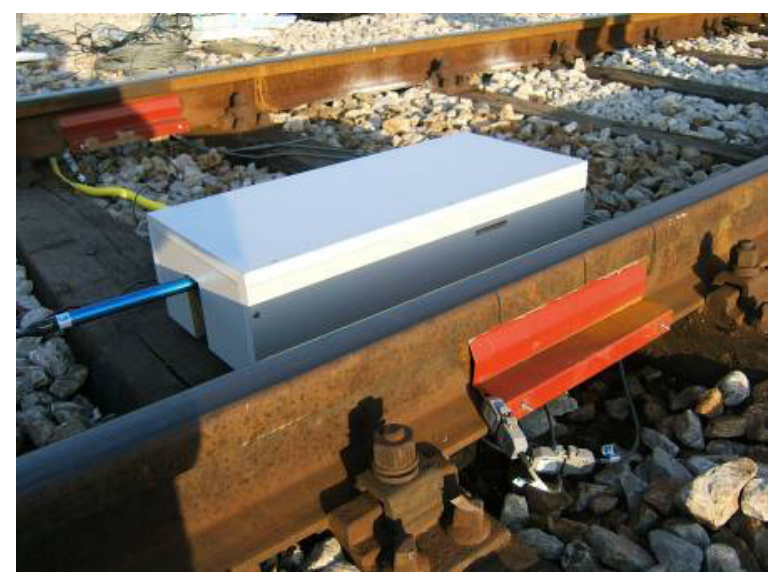

Figure 9. Laser system in ready-to-use position

In order to present application of the developed system, below we present some results of measurements performed on vehicles of Serbian Railways while passing through the curve with radius $214 \mathrm{~m}$ without the track superelevation (Figure 10). More detailed results of these experiments are given in [6]. The experiments were performed on three types of railway vehicles, including the shunting locomotive 621-301 and trailing and the tractive unit of electromotor train 412/416.

Within preparation, prior to measurements, perpendicularity of the laser beam to the rail was checked as described above. It appeared that the deviation from the perpendicularity $\gamma$ to rail tangent was $14.4 \mathrm{mrad}\left(0.83^{\circ}\right)$. According to previously presented conclusions, such a small deviation has negligible influence on AOA measurement uncertainty, so it was not necessary to correct the laser position.

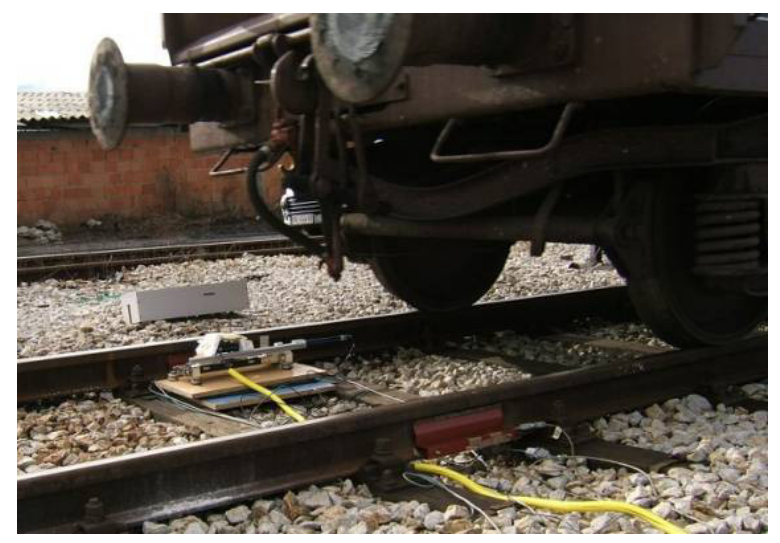

Figure 10. Trailing unit EMU 416-077 - angle of attack measurements [6]
Figure 11 presents the position of the outer wheels of the leading and the trailing wheelsets versus time, recorded by using the laser device.

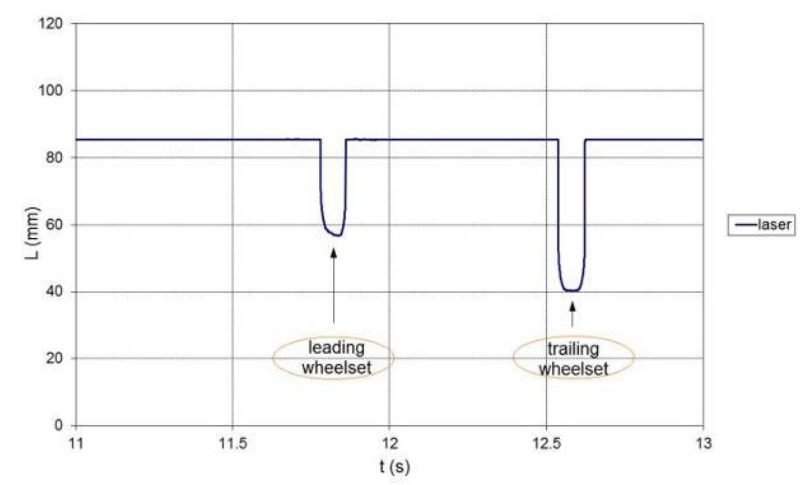

Figure 11. Trailing unit EMU 416-077 - outer wheels recorded data [6]

In order to get AOA the data were transformed to spatial domain. The details of the transformed data for the leading wheel are presented in Figure 12. The angle of attack $\alpha$ was calculated as the slope of the linear regression line of the central recorded segment, instead of using (5). Thus influences such as: (a) the curvature of the rail, (b) the rail lateral deflection, (c) the wheel and rail surface roughness etc. were compensated.

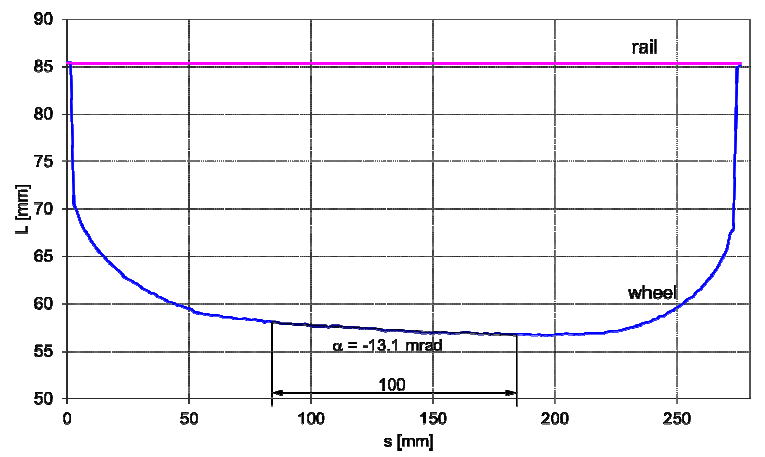

Figure 12. Trailing unit EMU 416-077 - relative position and angle of attack of the outer wheel of the leading wheelset [6]

The central part of the recorded signal with cca. 100 $\mathrm{mm}$ length is far enough from the rounded zones, caused by the wheel flange passing by the laser.

The obtained angle of attack for outer wheel of the leading wheelset was $\alpha=-13.100 \pm 0.011 \mathrm{mrad}$. The trailing wheelset has the angle of attack $\alpha=1.000 \pm 0.008$ mrad. The obtained results are in accordance with general theories [11] and expected values of this parameter for this type of vehicles.

\section{COMPARISON OF THE SIMULATION RESULTS WITH MEASUREMENTS}

Simulation of the railway vehicle dynamics using some of the specialized computer simulation packages may serve as a good design tool and also for estimation of the designed characteristics. Depending on the scope of an analysis, simulations can have very detailed models or can use some simplifications.

Within our research, using computer programme Vampire Pro [12], we included all the available 
parameters of the vehicle and the track, in order to make as realistic as possible input model for comparison with measurements. Figure 13 shows the non-linear model of the EMU series 412/416 indicating the details of bogie suspension elements [5]. The bogie frame and wheelsets are presented transparently in order to provide the better overview of the suspension system and link elements.

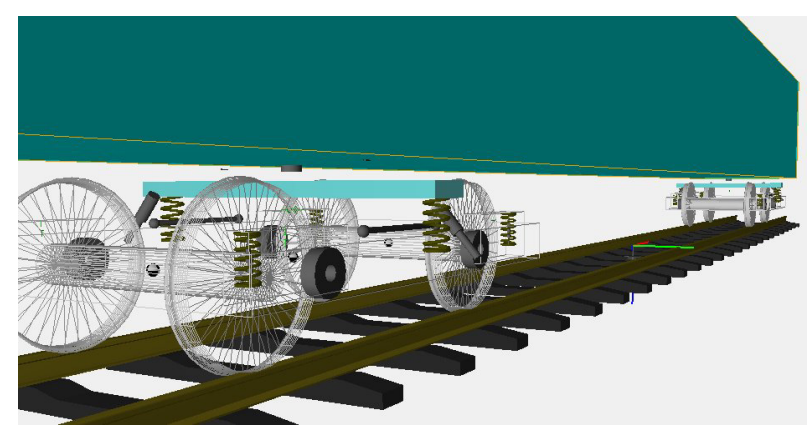

Figure 13. Model of EMU [5]

Used track model, including linear stiffness and damping characteristics between the rail and sleeper and the sleeper to ground, is shown in Figure 14. The rails and sleepers are considered to be massless degrees of freedom, which is appropriate for the steady-state curving analysis.

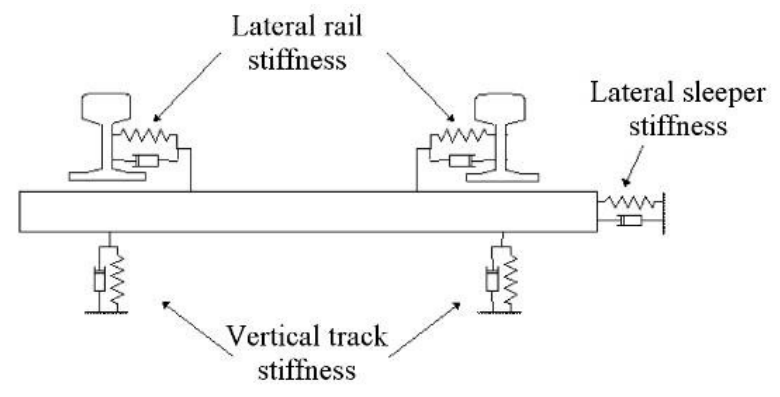

Figure 14. Track model [12]

Having in mind a strong dependence of the simulation results on the quality of the used input parameters, the results of the steady-state curving analysis have shown good agreement with experimentally obtained results for AOA. For curving analysis and other related analyses, such as the wheel/rail wear, the behaviour of the outer wheel of the leading wheelset is the most indicative parameter. In this case, the angle of attack of the leading wheelset obtained by simulation was equal to $-12.0 \mathrm{mrad}$, while the experimentally measured value was $-13.1 \mathrm{mrad}$. Although this means $9.2 \%$ difference, considering previously presented influences, this is a good result which additionally supports the validity of used measurement principle and adopted assumptions.

\section{CONCLUSIONS}

We analysed the uncertainty of specially designed laser system installed on track for the measurements of the wheel-rail angle of attack $\alpha$. The performed analysis showed that an accurate measurement using one laser device is possible, with acceptably low measuring uncertainty. It appeared that it is not even necessary to record the exact rail reference line, since the wheel forward movement direction represents the rail reference line.

For the selected measurement principle, the speed of the passing vehicle has the most important, but still low influence on the measurement uncertainty. The low measurement uncertainty is possible, if the perpendicularity between the laser beam and the rail longitudinal axis is kept within $\pm 5^{\circ}$, which is relatively easy to achieve.

Additionally, the obtained results were used for mutual validation of the experimental measurements and the results of the multibody system (MBS) simulations. It turned out that there exists a good agreement between these results, which further encourage experimental research in the railway vehicle dynamics using the presented measurement system.

\section{ACKNOWLEDGMENT}

The authors express the gratitude to the Ministry of Education and Science, Republic of Serbia research grants: TR 35006 and TR 35045.

\section{REFERENCES}

[1] Kanehara, H., Fujioka, T.: Measuring rail/wheel contact points of running railway vehicles, Wear, Vol. 253, pp. 275-283, 2002.

[2] Sugiyama, H., Tanii, Y., Suda, Y., Nishina, M., Komine, H., Miyamoto, T., Doi, H., Chen H.: Wheel/rail contact geometry on tight radius curved track: simulation and experimental validation, Multibody System Dynamics, Vol. 25, pp. 117-130, 2011.

[3] Iijima, H., Horioka, K., Kataori, A., Momosaki, S., Doi, K.: Development of Continuous Measurement Equipment for Angle of Attack and Results of Measurements, JR East Technical Review, Vol. 19, pp. 46-49, 2011.

[4] Izbinsky G., D'Aoust, D., Wayside Monitoring of the angle of attack of railway vehicle wheelsets, United States Patent, No. 5,368,260, Nov. 29, 1994.

[5] Milković, D.: The influence of the wheel-rail contact parameters on the railway vehicle dynamic behaviour, (in Serbian), $\mathrm{PhD}$ thesis, Faculty of Mechanical Engineering, University of Belgrade, Belgrade, 2012.

[6] Milković D., Simić G., Tanasković J., Jakovljević Ž., Lučanin V., Experimental and numerical determination of the wheel-rail angle of attack, Facta universitatis, Series: Mechanical Engineering, Vol. 13, No 2, pp. 123-131, 2015.

[7] Instruction manual optoNCDT 1700 - MICROEPSILON http://www.micro-epsilon.com/ download/manuals/man--optoNCDT-1700--en.pdf

[8] JCGM 100:2008, Evaluation of measurement data Guide to the expression of uncertainty in measurement, Joint Committee for Guides in Metrology, 2008.

[9] EN 13775-4: 2004 (E), Railway applications Measuring of new and modified freight wagons Part 4: Bogies with 2 wheelsets 
[10]EN 14363: 2005 (E), Railway applications Testing for the acceptance of running characteristics of railway vehicles - Testing of running behaviour and stationary tests

[11] Iwnicki, S., editor: A Handbook of Railway Vehicle Dynamics, CRC Press: Boca Raton, FL, 2006.

[12] VAMPIRE ${ }^{\circledR}$ Pro Version 5.50 Programme, DeltaRail Group Ltd., Derby 2011.

\section{МЕРНА НЕСИГУРНОСТ РЕЗУЛТАТА \\ МЕРЕЊА УГЛА НАЛЕТАЊА ТОЧКА НА ШИНУ ПОМОЋУ ЛАСЕРСКОГ СИСТЕМА ПОСТАВЉЕНОГ НА КОЛОСЕКУ}

Д. Милковић, Г. Симић, Ј. Танасковић, В. Лучанин, С. Радуловић
Угао налетања точка на шину је значајан параметар додира точак-шина. Заједно са силама које настају при том додиру, служи за оцену динамичког понашања шинског возила при проласку кроз кривину. У овом раду је анализирана мерна несигурност резултата мерења специјалним ласерским системом конструисаним за мерење угла налетања точка на шину, истичући значај теоријског приступа при избору одговарајућег мерног принципа и при идентификацији свих утицајних параметара. Разматран је и утицај правилног постављања и позиционирања система на колосеку на резултате мерења. Како би се оценио квалитет спроведене анализе, у раду су приказани неки од резултата мерења овим уређајем и њихово поређење са резултатима добијеним симулацијом, применом специјализованог софтверског пакета VAMPIRE Pro. 